\title{
Toxicity reduction and biodegradability enhancement of cork processing wastewaters by ozonation
}

\author{
A. C. Gomes, L. Silva, R. Simões, N. Canto and A. Albuquerque
}

\begin{abstract}
$\overline{\text { ABSTRACT }}$
Biodegradability enhancement and detoxification of cork boiling wastewater (CBW) are required for the successful implementation of biological treatment options. We studied the possibility of achieving these goals through ozonation pre-treatment by experimenting on the effect of ozone dose and $\mathrm{pH}$. The CBW used had a $\mathrm{pH}$ of 5.81, a chemical oxygen demand (COD) of 1,865 $\mathrm{mg} \mathrm{L}^{-1}, \mathrm{a}$ biochemical oxygen demand $\left(\mathrm{BOD}_{5}\right)$ of $498 \mathrm{mg} \mathrm{L}^{-1}$ and total phenol (TP) and tannin compounds concentrations of 523 and $399 \mathrm{mg} \mathrm{L}^{-1}$, respectively. The ozone doses ranged from 0.27 to 2.63 for the $\mathrm{O}_{3 \text { (applied) }} / \mathrm{COD}_{0}$ ratios with samples at natural $\mathrm{pH}$ and set to 3.33 and 9.96 . Ozonation allowed the $\mathrm{BOD}_{20} / \mathrm{COD}$ ratio (biodegradability index) to increase from 0.37 to 0.63 and a toxicity reduction from 3.08 to 1.24 TU (Microtox). The corresponding removals obtained were $15.2-62.0 \%, 38.4-83.2 \%$ and $56.7-92.1 \%$ for COD, TP and colour, respectively. The best outcome of ozonation pre-treatment requires $\mathrm{O}_{3 \text { (applied) }} / \mathrm{COD}_{0}$ ratios over 1.5 and an acid $\mathrm{pH}$. The increase of TP removals with ozone dose at acid $\mathrm{pH}$ led to biodegradability enhancement and CBW detoxification. However, for similar conditions the highest COD removals were obtained at alkaline pH due to the hydroxyl radicals' high oxidation ability but lack of selectivity.
\end{abstract}

Key words | biodegradability, cork wastewater, ozonation, toxicity

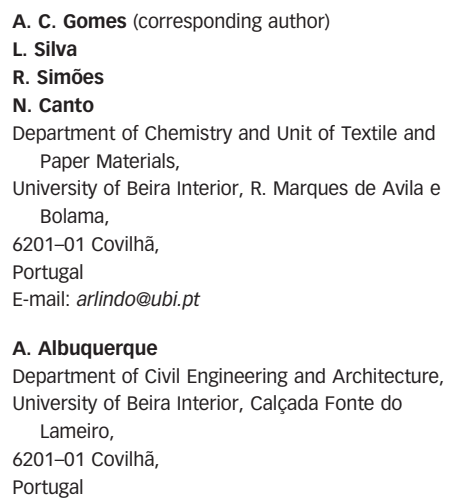

\section{INTRODUCTION}

The production of cork stoppers used to seal wine bottles is the most valuable product of the cork industry, which uses as raw material the outer bark of the Quercus suber $\mathrm{L}$. extracted from cork oak trees older than 20 years, after growth cycles of nine years for about 200 productive years (Pereira 2007). According to Mazzoleni et al. (2005), 15\% of the total cork production is used to manufacture cork stoppers, representing two-thirds of cork revenues. Therefore, the economic sustainability of cork production is closely dependent on the public's preference for stoppers made of cork to the detriment of synthetic materials. This competition can be overcome if cork production and transformation are perceived by consumers as environmentally sustainable activities. However, the first stage of the cork industrial processing is focused on the cleaning, disinfection and moistening of the raw material. For this purpose, the corkwood is immersed in boiling water up to one hour, depending on the contamination of the raw material and type of product; this processing water can be reused from six up to 30 times, which corresponds to a specific water consumption ranging from 0.35 to $0.70 \mathrm{~m}^{3} \mathrm{t}^{-1}$ (Mazzoleni et al. 2005; Dias-Machado et al. 2006; Mendonça et al. 2007). The resulting effluent presents a dark colour and contains some corkwood extracts such as phenolic acids, vegetable tannins and natural polyphenols. The nature and concentration of these compounds cause the effluent to be considered bio-recalcitrant and toxic (Dias-Machado et al. 2006; He et al. 2007; Mendonça et al. 2007). Summing up, the perception of cork as a 'green product' is also dependent on sustainable water use and pollution emission reduction by the cork processing industry.

The efficiency of wastewater treatment options based on biological processes requires wastewater to be biodegradable and non-toxic. In the case of cork boiling wastewaters $(\mathrm{CBW})$, the organic content is high, with the chemical oxygen demand (COD) ranging from 1.6 up to $5.5 \mathrm{~g} \mathrm{~L}^{-1}$, but the biological oxygen demand for 5 days incubation $\left(\mathrm{BOD}_{5}\right)$ is between 1.1 and $1.8 \mathrm{~g} \mathrm{~L}^{-1}$, which corresponds to a biodegradability index below the limit of $0.40-0.50$ for the $\mathrm{BOD}_{5} / \mathrm{COD}$ ratio necessary for considering effluents 
as biodegradable (Gilbert I987; Acero et al. 2004; Peres et al. 2004). Besides these features, the concentration of total phenols (TP) and tannic compounds, ranging from 287 to $995 \mathrm{mg} \mathrm{L}^{-1}$ and from 250 to $1,700 \mathrm{mg} \mathrm{L}^{-1}$, respectively, is associated with high acute toxicity to the bacterium Vibrio fischeri and the crustacean Daphnia magna, with 4.1 to 12.3 toxic units (TU) and between 3.4 and $11.5 \mathrm{TU}$, respectively (Mendonça et al. 2004; Peres et al. 2004; González et al. 2006).

Advanced Oxidation Processes have already been tested with CBW to achieve COD removal and biodegradability enhancement. For instance, Benitez et al. (2003) reported COD removals ranging from 12 to 54\% with ozonation, and Acero et al. (2004) achieved up to 90\% COD reduction for an oxidation stage combining $\mathrm{O}_{3}, \mathrm{H}_{2} \mathrm{O}_{2}$ and $\mathrm{UV}$ radiation. The sequence of Fenton's reagent and biological treatment, with microbial enriched cultures, resulted in total organic carbon removals above 90\% (Dias-Machado et al. 2006) and, in the case of the CBW pre-treatment by ozonation, an increment of COD removal from $13-37 \%$ to $67 \%$ was achieved by an activated sludge treatment system operating with retention times between 24 and $96 \mathrm{~h}$ (Benitez et al. 2003). However, up to date, the effect of $\mathrm{pH}$ on $\mathrm{CBW}$ ozonation has not yet been studied. The major limitation of the ozonation processes is their operational cost, particularly for close to complete mineralization operations, since the correlation between ozone efficiency and ozone dose is most frequently small (corresponding to a low yield for ozone oxidation). Additionally, the selectivity is influenced by solution $\mathrm{pH}$, radical scavengers' nature and concentration, causing ozone to be consumed in reactions with non-target compounds (Hoigné \& Bader 1976). In fact, to achieve full mineralization of hazardous organic compounds or to accomplish depuration of non-biodegradable effluents, according to environmental standards, by chemical oxidation, the involved costs are high when compared to those of biological treatment options (Oller et al. 20Io). However, ozonation is potentially attractive as a pre-treatment stage to enhance biodegradability and reduce toxicity of effluents containing recalcitrant or inhibitory compounds, allowing the depuration process to be completed by biodegradation. Nevertheless, this strategy requires confirmation that the resulting intermediates are assessed for biological degradation and less toxic than the original ones, otherwise incomplete oxidation may increase the toxicity of the wastewater (Lapertot et al. 2007).

Chemical oxidation with ozone is influenced by solution $\mathrm{pH}$; for $\mathrm{pH}$ values below 5.5 the hydroxyl radical $\left(\mathrm{OH}^{\circ}\right)$ formed by ozone self-decomposition is suppressed and molecular ozone $\left(\mathrm{O}_{3}\right)$ prevails (Hoigné \& Bader I976). Ozone is a very powerful oxidant $\left(\mathrm{E}^{\circ}=+2.07 \mathrm{~V}\right)$ that can react with numerous organic chemicals, namely with unsaturated organics, in a more selective way than the hydroxyl radicals, which are an extremely strong and nonselective oxidant through chain reactions $\left(\mathrm{E}^{\circ}=+3.06 \mathrm{~V}\right)$, with potential for oxidizing almost all organic pollutants, but with an effectiveness that can be reduced in wastewaters containing high concentrations of radical scavengers (Masten \& Davies 1994; Lapertot et al. 2007).

The objectives of this work were to study the influence of $\mathrm{pH}$ and ozone dose in oxidation trials run with $\mathrm{CBW}$ samples at natural $\mathrm{pH}$ and set close to 3 and 10 , to increase biodegradability and reduce toxicity, allowing the depuration process to be completed by biological treatment.

\section{METHODS}

\section{Cork processing wastewaters}

The CBW was collected from a cork processing plant located in the Portalegre district (Portugal) and kept frozen at $-18{ }^{\circ} \mathrm{C}$ until use. Prior to any experiment, the wastewater was filtered using 10 and $5 \mu \mathrm{m}$ pore size cartridge filters to remove gross suspended solids (SS). In mean terms, the pre-treatment allowed the reduction of the SS concentration by $55 \%$ (from 1,305 to $585 \mathrm{mg} \mathrm{L}^{-1}$ ).

\section{Analytical methods}

All the chemicals used were of analytical grade and the analytical determinations were carried out according to Standard Methods (APHA 2005), except for TP and tannin content, which were assessed by methodologies adapted from Folin \& Ciocalteau (I927) and Mukkar et al. (1993), respectively. The colour of the samples was measured by the absorbance at $580 \mathrm{~nm}$ (dilution 1:2) and the concentration of aromatic compounds at $254 \mathrm{~nm}$ (dilution 1:50). The $\mathrm{BOD}_{5}$ and $\mathrm{BOD}_{20}$ determinations were performed with an Oxitop OC system (WTW, Germany) according to the respirometric method (APHA 2005); this system allows monitoring of the oxygen consumption during the incubation period. The seed used was originally collected from an aeration reactor of an activated sludge system treating domestic wastewater and used after a 6-month preservation period in the laboratory in batch mode operation, using as carbon sources a mixture of glucose and acetate (with a COD of $2 \mathrm{~g} \mathrm{~L}^{-1}$ ), nutrients and micronutrients. The 
ecotoxicity was assessed by measuring the inhibition of the $V$. fischeri exposed to dilutions of wastewater samples before and after oxidation. The bioassays were carried out in a Microtox Model 500 Analyser with solutions and bacteria provided by Azur Environmental (Berkshire, UK). Samples were tested after $\mathrm{pH}$ adjustment to 7.0 and absorbance corrections were performed when sample dilutions were visibly coloured close to the calculated $\mathrm{EC}_{50}$ values. Toxicity data were computed and $\mathrm{EC}_{50}$ values were calculated according to the gamma method, using linear regression analysis of sample dilution as natural logarithm data versus percentage inhibition. All correlation coefficients were $>0.90$. The test results of these bioassays allowed us to obtain the $\mathrm{EC}_{50}-5 \mathrm{~min}$ and $\mathrm{EC}_{50}-15 \mathrm{~min}$ values, which were the dilution values of the samples that reduced the bacterial light emission by $50 \%$ after 5 and 15 minutes exposure, respectively. The dilution values (sample volume/total volume) were converted into TU (corresponding to the inverse of the dilution values). Regarding the oxidation trials, the ozone consumption was calculated by the difference between ozone feed and ozone at the exit of the reactor for discrete intervals of time (10 min) trapped in $200 \mathrm{~mL}$ of $\mathrm{KI}$ at $2 \%$. The oxidation reaction is terminated by bubbling pure oxygen for at least $15 \mathrm{~min}$ before collecting the samples from the closed reaction vessel. Additionally, to ensure complete depletion of residual ozone, we waited at least two hours before starting the bioassays for biodegradability and toxicity assessment.

\section{Experimental set-up}

A Fischer Model 502 (Bonn, Germany) ozone generator was employed to produce ozone from dry, pure oxygen. The ozone concentration in the gas phase was in the range of $46-50 \mathrm{mg} \mathrm{L}^{-1}$ and the volumetric flow rate was set to $50 \mathrm{~L} \mathrm{~h}^{-1}$, corresponding to an average production of $40 \mathrm{mg} \mathrm{O}_{3} \mathrm{~min}^{-1}$. The ozonation trials of the $\mathrm{CBW}$ were carried out in a closed vessel of $1 \mathrm{~L}$ provided with a mechanical stirrer to promote ozone dissolution in the aqueous medium with applied ozone doses $\left(\mathrm{O}_{3 \text { applied }}\right)$ ranging from 496 to $4,990 \mathrm{mg}$. The ozonation trials were carried out at $20 \pm$ $1{ }^{\circ} \mathrm{C}$ and lasted 10, 20, 40, 60 and $100 \mathrm{~min}$.

\section{RESULTS AND DISCUSSION}

The values obtained for the CBW characterization after prefiltration were: $\mathrm{pH}=5.81$, COD of $1,878 \mathrm{mg} \mathrm{L}^{-1}$, BOD of 498 and $684 \mathrm{mg} \mathrm{L}^{-1}$, after 5 and 20 days' incubation, respectively. The TP concentration was $523 \mathrm{mg} \mathrm{L}^{-1}$ and the tannic content was $399 \mathrm{mg} \mathrm{L}^{-1}$, the absorbance at $254 \mathrm{~nm}$ (dilution 1:50) was 0.562 and the brownish colour measured at $580 \mathrm{~nm}$ (dilution 1:2) was 0.554 . The main features of this wastewater were the low biodegradability, with a $\mathrm{BOD}_{5} / \mathrm{COD}$ ratio of 0.27 and $\mathrm{BOD}_{20} / \mathrm{COD}$ ratio of 0.37 , and the acute toxicity, measured by the Microtox test, which was 3.08 and $3.46 \mathrm{TU}$ for $\mathrm{EC}_{50}-5 \mathrm{~min}$ and $\mathrm{EC}_{50}-15 \mathrm{~min}$ respectively, suggesting that biological treatment was ineffective. It is worth noting that the BOD of the CBW after 5 days' incubation did not reach a steady value, possibly because the biological oxidation of the organic compounds, namely low molecular weight and oligomeric polyphenols, such as tannins, phenolic acids, chlorophenols and other organic compounds, proceeds very slowly. Therefore, despite $\mathrm{BOD}_{5}$ being the parameter usually considered in regulations and the $\mathrm{BOD}_{5} / \mathrm{COD}$ ratio used as biodegradability index, we increased the incubation time to 20 days, which proved to be enough to have a constant value for the $\mathrm{BOD}$ in all cases. The $\mathrm{BOD}_{5}$ and $\mathrm{BOD}_{20}$ values show that close to $73 \%$ of the biodegradable matter is accessed by microorganisms within 5 days of incubation and the biological oxidation of the remaining fraction is more difficult to accomplish. These values are close to those found in urban wastewater, with a $\mathrm{BOD}_{5} / \mathrm{BOD}_{20}$ ratio of 0.75 but the concentration of organics in the case of the $\mathrm{CBW}$ is over the range of values typically found in domestic wastewaters, with $\mathrm{BOD}_{5}$ values ranging from 100 to $300 \mathrm{mg} \mathrm{L}^{-1}$ (Metcalf \& Eddy 1993). Therefore, CBW pre-treatment is required to increase the viability of biological treatment systems.

The alteration of the samples' $\mathrm{pH}$ is required for several physicochemical treatment processes, namely with Fenton's reagent (Dias-Machado et al. 2006), coagulation/flocculation (Peres et al. 2004) and solar photocatalytic process (Vilar et al. 2008) and was tested by us for ozonation experiments with $\mathrm{CBW}$ for $\mathrm{O}_{3 \text { (applied) }} / \mathrm{COD}_{0}$ ratios ranging from 0.27 to $2.52,0.27$ to 2.63 and 0.28 to 2.26 , for acid ( $\mathrm{pH}$ 3.33), natural ( $\mathrm{pH} 5.81$ ) and alkaline $\mathrm{pH}(\mathrm{pH} 9.96)$, respectively. The alkaline $\mathrm{pH}$ tends to allow hydroxyl radicals to prevail to the detriment of molecular ozone during the oxidation reactions. However, setting the $\mathrm{pH}$ close to 10 only guarantees a $\mathrm{pH}$ over 5.5 for oxidation reactions up to $20 \mathrm{~min}$; for longer reaction times the prevailing oxidant will be molecular ozone. The $\mathrm{pH}$ decay with ozonation is a well-known consequence of the conversion of pollutants into organic acid of lower molecular weight. The yield for the supplied ozone, corresponding to the ratio between consumed ozone and supplied ozone, was always higher for 
alkaline $\mathrm{pH}$, ranging from 40.3 to $90.8 \%$, and was between 42 and $85.3 \%$, and 32.6 and $79.4 \%$ for natural and acid $\mathrm{pH}$, respectively. The reduction of $\mathrm{COD}$ at alkaline $\mathrm{pH}$ was also above the values achieved for the other $\mathrm{pH}$ values (Figure 1(a)). For the highest ozone doses (corresponding to 4,235, 4,788 and 4,990 $\mathrm{mg}$ of $\mathrm{O}_{3}$ for alkaline, acid and natural $\mathrm{pH}$, respectively), the COD removals were 53.4\%, 58.8 and 62\% for acid, natural and alkaline $\mathrm{pH}$, respectively. It is worth noting that the ozone yield decays with reaction time and was below 50\% after 60 min reaction (ozone doses ranging from 1,324 to $1,782 \mathrm{mg}$ ), which limits the practicability of ozonation and points to the need to drive the oxidation for biodegradability improvement and detoxification to the detriment of mineralization. Ozone doses corresponding to $\mathrm{O}_{3 \text { (applied) }} / \mathrm{COD}_{0}$ ratios ranging from 1.50 to 1.72 (60 min reaction) were sufficient to increase the $\mathrm{BOD}_{20} / \mathrm{COD}$ ratio up to 0.50 for samples at acid and natural $\mathrm{pH}$ and over 0.40 for the alkaline $\mathrm{pH}$ values (Figure 1(b)), allowing biodegradation.

As the ozonation time increases from 10 to $100 \mathrm{~min}$ (corresponding to $\mathrm{O}_{3 \text { (applied) }} / \mathrm{COD}_{0}$ ratios ranging from 0.27 to 2.63 ), the remaining substrates are increasingly recalcitrant to oxidation and the stoichiometric ratios (corresponding to the ratio between COD removal and the amount of consumed ozone) exhibit a significant decay from 0.72 to 0.65 , from 0.70 to 0.52 and from 0.96 to 0.56 , for acid, natural and alkaline $\mathrm{pH}$, respectively, showing another important economic constraint. For these ozone dose ranges, the colour removals were 56.7-90.8\%, $58.7-92.1 \%$ and $66.0-83.2 \%$ for oxidation trials at natural, alkaline and acid $\mathrm{pH}$, respectively. However, the oxidized effluents were slightly brownish coloured in all cases. Similar reductions of the absorbance at $254 \mathrm{~nm}$, resulting from the concentration of aromatic compounds, were achieved and corresponded to the direct or indirect attack of molecular ozone or free radicals produced by ozone decomposition, respectively, on compounds having carbon-carbon double bonds (Masten \& Davies I994).

The biodegradability increase was more dependent on ozone selectivity than on COD removal, since smaller COD reductions at acid $\mathrm{pH}$ corresponded to a higher $\mathrm{BOD}_{20} / \mathrm{COD}$ ratio increase (Figure 1). Therefore, the increase of ozone doses supplied at alkaline $\mathrm{pH}$ may result in the oxidation of biodegradable pollutants instead of the toxic and recalcitrant ones. Interestingly, the advantage of molecular ozone for CBW biodegradation can be correlated with the degradation of phenolic compounds (Figure 2(a)); which is very fast at $\mathrm{pH} 3.33$, since with an $\mathrm{O}_{3 \text { (applied) }} /$ $\mathrm{COD}_{0}$ ratio of 1.10 the reduction obtained was already 76.9 and only increases up to $83.2 \%$ with an ozone dose (a)

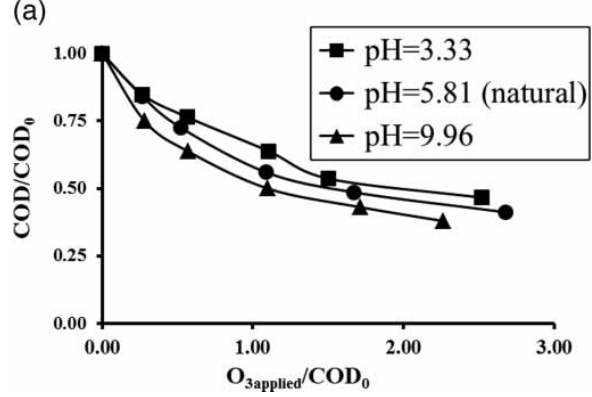

(b)

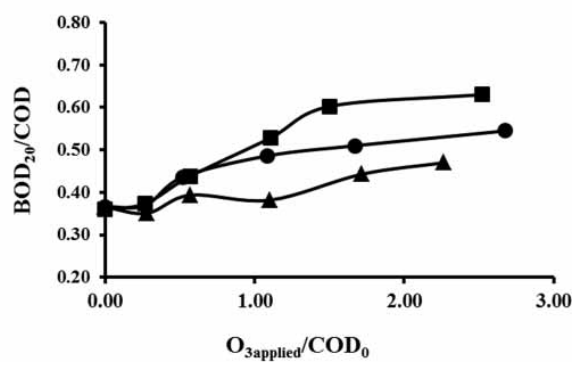

Figure 1 | Influence of $\mathrm{pH}$ and ozone doses on the reduction of $\mathrm{COD}$ (a) and biodegradability enhancement (b).

(a)

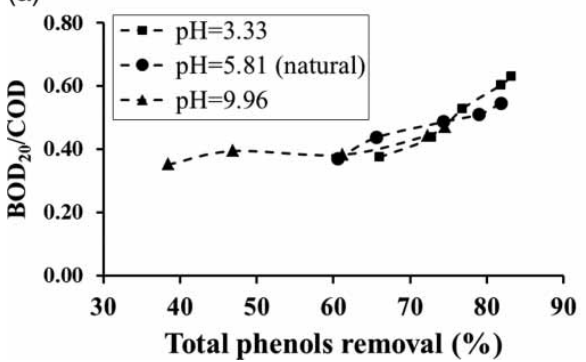

(b)

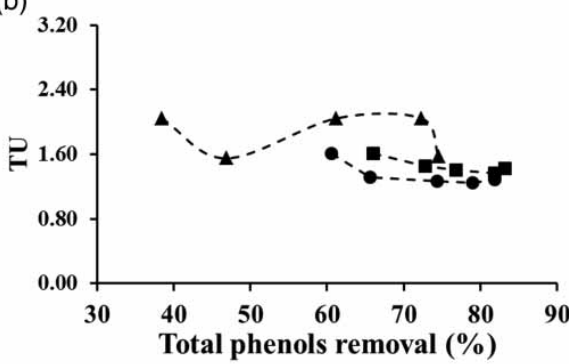

Figure 2 | Variation of the biodegradability $\left(\mathrm{BOD}_{20} / \mathrm{COD}\right.$ ratio) (a) and toxicity (b) as a function of $\mathrm{pH}$ and total phenols removal. 
rise to 2.52. TP degradation ranged from 38.4 to $74.6 \%$ at alkaline $\mathrm{pH}$ and corresponded to the less favourable conditions, with the natural $\mathrm{pH}$ allowing intermediate removals. These results are possibly the consequence of the lower selectivity of the hydroxyl radicals when compared to molecular ozone for the oxidation of phenolic compounds (Hoigné \& Bader I985).

The other goal of ozonation pre-treatment, the CBW detoxification, was also accomplished at acid and natural pH. But, in these cases, the correlation between TP removal and toxicity was not so clear, namely for alkaline $\mathrm{pH}$ (Figure 2(b)). However, these results may be a consequence of the high sensitivity of $V$. fischeri bacteria to the large variety of compounds resulting from the lack of selectivity of hydroxyl radical reactions, which are reacting with other pollutants rather than phenolic compounds. Therefore, the best results for ozonation pre-treatment are obtained when the oxidation is based on the selectivity of molecular ozone for phenolic compounds. It is also worth noting that the concentration of tannin compounds closely follows the variation reported for phenolic compounds.

\section{CONCLUSIONS}

The organic load on the CBW sample was high, with a COD of $1,878 \mathrm{mg} \mathrm{L}^{-1}$; but having a low biodegradability of 0.27 and 0.37 for the $\mathrm{BOD}_{5} / \mathrm{COD}$ and $\mathrm{BOD}_{20} / \mathrm{COD}$ ratios, respectively. Additionally, only $73 \%$ of the biodegradable matter is easily accessed by microorganisms and the Microtox bioassay revealed a high acute toxicity of 3.08 TU for an exposure time of $5 \mathrm{~min}$. These features prevent the successful application of biological treatment. Therefore, we studied the possibility of achieving CBW biodegradability enhancement and detoxification by ozonation pre-treatment, allowing depuration to be completed by biodegradation. The ozone doses experienced ranged between 0.27 and 2.63 for the $\mathrm{O}_{3 \text { (applied) }} / \mathrm{COD}_{0}$ ratios with samples at natural $\mathrm{pH}$ (5.81), set to acid (3.33) and alkaline (9.96). For similar ozone doses, the highest COD removals were obtained at alkaline $\mathrm{pH}$, with 25-62\%; and with the TP concentration reduction the highest percentages were obtained at acid $\mathrm{pH}$ and ranged from 66.0 to $83.2 \%$. However, in order to increase biodegradability it is preferable to have TP concentration reduction rather than COD removal, since for higher TP removals we obtained increments of the $\mathrm{BOD}_{20} / \mathrm{COD}$ ratio up to 0.63 at acid $\mathrm{pH}$. Therefore, it is preferable to set reaction conditions that allow the presence of molecular ozone to the detriment of the more reactive but less selective hydroxyl radicals, i.e. pH values below 5.5 (acid). The correlation between TP concentration and sample toxicity was also established but was less evident.

The major limitation of the ozonation pre-treatment option results from the significant ozone yield decay with reaction time, which was below 50\% after 60 min reaction (corresponding to ozone doses between 0.71 and 0.95 for the $\mathrm{O}_{3 \text { (applied) }} / \mathrm{COD}_{0}$ ratio). However, these ozone doses were sufficient to increase the $\mathrm{CBW} \mathrm{BOD}_{20} / \mathrm{COD}$ ratio over 0.40 for alkaline $\mathrm{pH}$ and over 0.50 for acid to natural $\mathrm{pH}$ values.

\section{ACKNOWLEDGEMENT}

The authors are thankful for the financial support from FCT (PTDC/AGR-AMM/102042/2008).

\section{$\overline{\text { REFERENCES }}$}

Acero, J. L., Benitez, F. J., de Heredia, J. B. \& Leal, A. I. 2004 Chemical treatment of cork-processing wastewaters for potential reuse. Journal of Chemical Technology and Biotechnology 79 (10), 1065-1072.

APHA 2005 Standard Methods for the Examination of Water and Wastewater, 21st edn, American Public Health Association/ American Water Works Association/Water Environment Federation, Washington, DC, USA.

Benitez, F. J., Acero, J. L., Garcia, J. \& Leal, A. I. 2003 Purification of cork processing wastewaters by ozone, by activated sludge, and by their two sequential applications. Water Research 37 (17), 4081-4090.

Dias-Machado, M., Madeira, L. M., Nogales, B., Nunes, O. C. \& Manaia, C. M. 2006 Treatment of cork boiling wastewater using chemical oxidation and biodegradation. Chemosphere 64 (3), 455-461.

Folin, O. \& Ciocalteau, V. I927 On tyrosine and tryptophane determinations in proteins. Journal of Biological Chemistry 73 (2), 627-650.

Gilbert, E. 1987 Biodegradation of ozonation products as a function of COD and DOC elimination by example substituted aromatic substances. Water Research 21 (10), 1273-1278.

González, T., Domínguez, J. R., Beltrán-Heredia, J., García, H. M. \& Sanchez-Lavado, F. 2006 Aluminium sulfate as coagulant for highly polluted cork processing wastewater: Evaluation of settleability parameters and design of a clarifier-thickener unit. Journal of Hazardous Materials 148 (1-2), 6-14.

He, Q., Yao, K., Sun, D. \& Shi, B. 2007 Biodegradability of tannincontaining wastewater from leather industry. Biodegradation 18 (1), 465-472.

Hoigné, J. \& Bader, H. 1976 The role of hydroxyl radical reactions in ozonation process in aqueous solutions. Water Research 10 (5), 377-386. 
Hoigné, J. \& Bader, H. 1985 Rate constants of reactions of ozone with organic and inorganic compounds in water - III (inorganic compounds and radicals). Water Research 19 (8), 993-1004.

Lapertot, M., Ebrahimia, S., Ollerc, I., Maldonado, M. I., Gernjakc, W., Malato, S. \& Pulgarín, C. 2007 Evaluating Microtox $^{(\mathcal{C}}$ as a tool for biodegradability assessment of partially treated solutions of pesticides using $\mathrm{Fe}^{3+}$ and $\mathrm{TiO}_{2}$ solar photo-assisted processes. Ecotoxicology and Environmental Safety 69 (3), 546-555.

Masten, S. J. \& Davies, S. H. R. 1994 The use of Ozonation to degrade organic Contaminants in wastewaters. Environmental Science and Technology 28 (4), 180-185.

Mazzoleni, V., Dallagiovanna, L., Trevisan, M. \& Nicelli, M. 2005 Persistent organic pollutants in cork used for production of wine stoppers. Chemosphere 58 (11), 1547-1552.

Mendonça, E., Pereira, P., Martins, A. \& Anselmo, A. M. 2004 Fungal biodegradation and detoxification of cork boiling wastewaters. Engineering in Life Sciences 4 (2), 144-149.

Mendonça, E., Picado, A., Silva, L. \& Anselmo, A. M. 2007 Ecotoxicological evaluation of cork-boiling wastewaters. Ecotoxicology and Environmental Safety 66 (3), 384-390.
Metcalf \& Eddy I993 Wastewater Engineering. Treatment and Reuse, 3rd edn, Metcalf and Eddy, Inc., McGraw-Hill, Inc. International Editions, New York, USA, pp. 359-435.

Mukkar, H. P. S., Blummel, M., Borowy, M. \& Becker, N. K. I993 Gravimetric determination of tannins and their correlations with chemical and protein precipitation methods. Journal of the Science of Food and Agriculture 61 (2), 161-165.

Oller, I., Malato, S. \& Sánchez-Pérezb, J. A. 2ого Combination of Advanced Oxidation Processes and biological treatments for wastewater decontamination - A review. Science of the Total Environment 409 (20), 4141-4166.

Pereira, H. 2007 Cork: Biology, Production and Uses. Elsevier Science, 1st edn. Amsterdam, Netherlands, pp. 127-144.

Peres, J. A., de Heredia, J. B. \& Domínguez, J. R. 2004 Integrated Fenton's reagent - coagulation/flocculation process for the treatment of cork processing wastewaters. Journal of Hazardous Materials 107 (3), 115-121.

Vilar, V. J. P., Maldonado, M. I., Oller, I., Malato, S. \& Boaventura, R. A. R. 2008 Solar Treatment of cork boiling and bleaching wastewaters in a pilot plant. Water Research 43 (16), 4050-4062.

First received 10 January 2013; accepted in revised form 22 July 2013. Available online 22 October 2013 